\title{
Sempu Island: Natural Conservation Versus Tourism
}

\author{
Irma Fitriana Ulfah ${ }^{1}$, Ruth Agnesia Sembiring ${ }^{2}$, Dhikna Ajeng Novikha Arie ${ }^{3}$ \\ \{i.fitriana@ub.ac.id ${ }^{1}$,nesi.biring@gmail.com ${ }^{2}$, dhikna.ajeng@gmail.com ${ }^{3}$ \}
}

Universitas Brawijaya, Indonesia ${ }^{1,2,3}$

\begin{abstract}
This article focuses on state of dualism in Sempu Island, which is located on Malang Regent as nature conservation and tourism destination. Sempu Island as conservation site, laid under Natural Resources Conservation Center Regional East Java (BBKSDA), and supported by BKSDA Resort as wildlife management authority whom responsible for Sempu Island Conservation Site. As conservation site, Sempu Island has uniqueness, which consist of mangrove forest, seaside forest, lowland tropical rainforest and Segara Anakan. On the other side, Sempu Island is appointed as tourism destination by local government in Tambakrejo Village, Malang Regency. The local government of Tambaksari Village issued Bill no. 3 of 2015 article 19, which regulated Sempu Island as restricted tourism destination. Nevertheless, so far the accountability of funding management of Sempu Island retribution by local/ village government is somehow questionable. Eventually based on public consultation started from 2019, the status of Sempu Island is transformed into nature conservation. It brings future challenges for Sempu Island management in accordance with its status as nature conservation which can only be used for specific purpose as a compliance for its new status and a new rule that state stated all visitor should have permit issuance (SIMAKSI).
\end{abstract}

Keywords: Sempu Island, Natural Conservation, Tourism.

\section{Introduction}

Sempu Island is one of the group of islands located in Tambakrejo Village, Sumbermanjing District, Malang Regency (See figure 1). It is the only area in Java that bears the status of a conservation area in the form of an island. Sempu Island was designated as a nature reserve based on the Decree of the Governor-General of the Dutch East Indies (Besluit van den Gouverneur General van Nederlandsch Indie) Number 46 Stbl. 69 March 15, 1928 concerning Aanwijzing van het natourmonument Poelau Sempoe with an area of $\pm 877 \mathrm{Ha}$. Raison d'etat for its establishment as natural rconservation arise since it has the uniqueness of several types of ecosystems including mangrove forest ecosystems, coastal forests and lowland tropical rain forests and Segara Anakan [1].

East Java BBKSDA Regional Office as the authorized management of the Sempu Island nature conservation, assisted by the Sempu Island BKSDA Resort, must tighten guard and had to be more assertive to ban tourists. This policy based on the mandate of the Sempu Island Nature Reserve Area Law, Law Number 5 of 1990 concerning Conservation of Biological Resources and Ecosystems. The law states: "A nature conservation is a nature reserve because its natural state has unique features, animals and ecosystems or certain ecosystems that need to be protected and their development takes place naturally" [2][3]. In more detail explained in article 17, it states the activities permitted in the Sempu Island region are only for research and 
development activities in science, education and activities that support the area's cultivation. This law was also followed up with the Government Regulation Number 28 of 2011 concerning Management of Nature Reserves and Nature Conservation Areas. Based on the government regulation above in article 33, it explains that:

"Nature conservation will be used for research and development activities in science, education and awareness raising for nature conservation, carbon sequestration and / or storage, and utilization of bio-diversity's sources to support cultivation" [4].

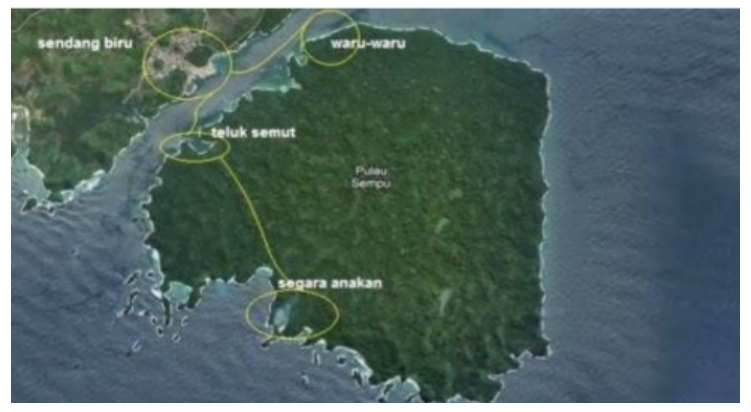

Fig. 1. Sempu Island's Entrance Map

Referring to the research conducted by Pratama, it explained that the inauguration of Sempu Island as a nature conservation was in accordance with its establishment policy. However, Sempu Island establishment as a nature conservation is actually followed by the increasingly rampant tours to visit Sempu Island [5]. Based on data from tourist visitors on Sempu Island, it shows a significant increase in 2013-2014. The number of visitors to Sempu Island can be seen in detail in the table below:

Table 1. Visitors

\begin{tabular}{ll}
\hline Year & Visitors \\
\hline 2011 & 10.879 \\
2012 & 1.041 \\
2013 & 30.000 \\
2014 & 22.856 \\
2015 & 2.528 \\
2016 & 0
\end{tabular}

Sources: Field of KSDA Regional I, II, III Section of Service and Utilization.

Based on the data above, it shows that although the status of Sempu Island is installed as a nature conservation, but the number of visitors is still high and contributes to the community around Sempu Island. Some society that support the existence of tourists on Sempu Island such as boat owners who cross from Sendang Biru Beach to Sempu Island, tour guides, food and beverage vendors, homestay owners, and fishermen who depend their lives on Sempu Island.

All tourism activities in the Sempu Island area are prohibited including illegal tourism. Lack of understanding from the locals is inversely proportional with the island's utilization. The locals have long assumed that Sempu Island is part of the Sendang Biru tourist attraction. Even though the BKSDA Resort has provided information to the locals, there are still people who 
continue to provide tourist guide services to Sempu Island despite a ban from officials. Another obstacle from the supervision of Sempu Island is due to the lack amount of guard officers, which is not sufficiently enough to the guard the whole area of Sempu Island which can be entered from various other sea lanes. Officials at the Bempa Resort of Sempu Island consist of only four people and are certainly overwhelmed to guard Sempu Island which has an area of 877 hectares.

Other problems that occur related to Sempu Island are referring to the research result conducted by Basyori (2015). He argues that conflicts whom occurs on Sempu Island is due to several things, including: (i) differences in perceptions between actors in enforcing existing rules. (ii) law enforcement from BBKSDA of East Java Province and BKSDA Resort of Sempu Island were quite low. (iii) the legitimacy of BBKSDA in East Java has been widely opposed by the locals. (iv), omission of violations of the existing rules concerning with the boundaries leads to neglect of these rules [6].

This paper emphasizes on the follow-up of this dualism, which positioned Sempu Island as a nature conservations and tourist destination, by making blocks on Sempu Island which consist of protection, rehabilitation, and religious, cultural/historical blocks.

\section{Literature Review}

As mentioned in previous chapter, the existing research mostly focused on policy evaluations [5]. The results of his research indicate that the inauguration of Sempu Island as a nature conservation is in accordance with its policy. However, the existence of tourism activities led to the failure of Sempu Island conservation. Another literature based on his research Basyori (2015) discusses the Conflict Management in Sempu Island Nature Conservation, as explained in the introduction. Furthermore, research conducted by Purnomo, Sulistyantara, and Gunawan (2013) shows that the Sempu Island Nature Reserve area has the potential to be developed into an ecotourism destination with the attraction of natural attractions such as the lake "Segara Anakan", diversity of flora, fauna and its ecosystem. The recommendations of this study are to evaluate the function of the area and divide the management block to minimize the impact of visitors; b) Change of status as a Nature Reserve area to become a Nature Tourism Park; c) Doing collaborative management of the area with the community [7].

Based on previous research traces above, it can be concluded that the status of Sempu Island can be used as a nature conservation as well as tourism. Therefore, this paper observes at the dualism of Sempu Island's new statuses. This dualism is examined from the actor which is explained by Bryant and Bailey.

According to Bryant and Bailey, environmental problems cannot be separated from the political economy's problem. Therefore, concerning with the dualism of the status of Sempu Island, it cannot be separated with the political economy. In detail, Bryant and Bailey map there are 5 approaches in understanding political ecology [8]:

a) Focusing on specified ecological problem, i.e. how human being affected physical environment;

b) Focus on the question of political ecology which explores o how the concepts are constructed. Discourse analysis seems dominant in this approach, for example the concept of sustainable development in order to clarify the basic assumptions about society and nature, as well as the political economy that makes these assumptions exist;

c) Approach which sees political problem is related with ecological problem in specified geographic context; 
d) Approach which explores political ecology question, whom relates on social-economic character such as social class, gender and ethnic;

e) Approaches which emphasizes on the needs to focus on interest, characteristic, and actions from the actors in order to understand political and ecological problem.

Based on the five approaches above, this paper focuses on examining the approaches to the interests and actions of actors. Furthermore, this actor's approach has several basic assumptions [8]: first, the costs and benefits related to environmental changes are enjoyed by the actors unevenly. Second, the uneven distribution of costs and benefits encourages the creation of socioeconomic inequalities. Third, the different socioeconomic impacts of these environmental changes also have political implications in the sense that there is a change in power in the relationship of one actor to another.

\section{Method}

This research uses qualitative research whom describes as are one type of research that aims to explain phenomena through deep data collection [9]. Qualitative research is also defined as a type of research whose findings are not obtained through statistical procedures or other forms of calculation [10]. This qualitative research uses descriptive type because it aims to make a systematic, factual, and accurate description of the facts and properties of certain objects [9]. The qualitative descriptions methods is used to describes interesting findings related to dualism status in Sempu Island [9].

Data collection techniques are done by interview and documentation. Documents are one of the data collection techniques that can be accounted for, for several reasons as follows: documents are a stable, rich and encouraging source, useful as evidence, are natural, not reactive, so that the results of the study will expand the knowledge related to the object under study.

\section{Result and Discussion}

As a nature conservation, Sempu Island is under the East Java Natural Resources Conservation Center and Sempu Island BBKSDA Resort. The status of Sempu Island as a nature reserve is supported by the NGO Profauna and Friends of Nature Indonesia. Other parties who use Sempu Island as a tourist destination are the support of the Tambakrejo Village Government and BPD Tambakrejo Village and the surrounding community who depend their lives from Sempu Island. These communities are home stay owners, food stalls, tour boat owners, tour guides, and fishermen.

\subsection{Sempu Island as Nature Conservation}

Sempu Island as a nature reserve is under the BBKSDA of East Java and is assisted by the Sempu Island BBKSDA Resort. East Java BBKSDA is tasked with carrying out management of the Sempu Island nature reserve in Tambakrejo Village, Sumbermanjing District, Malang Regency. In detail, the task of BBKSDA East Java is to carry out conservation of nature conservation and their ecosystems in nature reserves, wildlife reserves, nature parks and hunting 
parks as well as technical coordination in the management of grand forest parks and essential ecosystem areas based on statutory provisions. In carrying out these tasks, East Java BBKSDA organizes functions, such as [11]:

a) Inventorying potential, spatial management and preparation of management plans for nature conservation, wildlife reserves, nature tourism parks and hunting parks;

b) Implementation of protection and security of nature reserves, wildlife conservation, nature tourism parks, hunting parks;

c) Mitigation of ecological impact of national resources damage;

d) Control of forest fires in nature reserves, wildlife reserves, nature tourism parks and hunting parks;

e) Management of wild plant and animal species and their habitats as well as genetic resources and traditional knowledge;

f) Development and utilizing of ecological service;

g) Evaluation of functional suitability, ecosystem restoration and area closure;

h) Preparation for establishment and operationalization of Conservation Forest Management Units (KPHK);

i) Provision of data and information, promotion and marketing of conservation of natural resources and their ecosystems;

j) Development of cooperation and partnerships in the conservation of natural resources and their ecosystems;

k) Supervision and control of the distribution of wild plants and animal;

1) Technical coordination on the determination of wildlife corridors;

m) Technical coordination of management of major forest parks and essential ecosystem areas;

n) Developing the development of natural love and counselling on conservation of natural resources and their ecosystems;

o) Community empowerment in and around conservation areas;

p) Implementation of administrative and household affairs and public relations.

The BBKSDA Resort only serves as a field supervision function. Patrol Sempu Island to ensure no visitors enter without permission and control the flora and fauna habitat that exists on Sempu Island. Supervision is currently carried out more concentrated on illegal tourists entering Sempu Island. Permission to enter Sempu Island is based on Regulation of the Director General of Forest Protection and Nature Conservation Number: P7/iv-set/2011 which must have a Conservation Area Entry Permit (SIMAKSI).

The benefits of Sempu Island as a nature reserve when viewed from the side of the government, this is as a form to preserve the natural resources owned by Indonesia. But on the other hand, if Sempu Island is used as a nature reserve then there are some parties who have to bear the negative impacts of the surrounding communities who depend their lives from Sempu Island.

The use of Sempu Island as a nature reserve should be supported by non-governmental organizations that are active in guarding environmental issues. Like for example PROFAUNA and the Coalition of nature lovers Sempu Island, represented by the Friends of Nature Indonesia (SALAM). Both of these NGOs actively oversee the discourse of changing the status of Sempu Island to become a tourist destination. The activity carried out by SALAM is to provide the general public with an understanding of the condition and status of the Sempu Island nature reserve. Meanwhile, according to Sahid [12] PROFAUNA currently has a role in field action, by forming a ranger team that seeks to assist BKSDA Sempu Island resort officers in guarding 
and conducting patrols to prevent the entry of illegal tourists. In addition to joint patrol efforts, the ranger is also tasked with providing education to Sendang Biru tourist visitors so as not to cross into Sempu Island. Although based on field observation due to the limited personnel of the ranger team so that it cannot work optimally.

\subsection{Sempu Island as a Tourist Area}

Utilization of Sempu Island as a tourist area was once supported by Tambakrejo village government of 2011-2017 period. At that time, they issued Tambakrejo Village Regulation Number 03 of 2015 concerning Customary, Administration and Development and the Environment Law which included charge on parking fees for visitors to enter Sempu Island and submission of Sempu Island status to become a tourist area.

Based on these regulations, the surrounding community utilizes Sempu Island for economic purposes. Aside from the village government's it also benefits the local residents. Although in actualization it turns out there is no transparency from the village government in related to income and benefits from the existence of tourism activities on Sempu Island. The current village government, for period of 2017-2022, does not continue the previous government policy regarding the use of Sempu Island as a tourism destination.

Utilization of Sempu Island as a tourist area due to the existence of several surrounding communities whom their lives depend from Sempu Island. These economic reasons make some member of communities' support Sempu Island to be opened to tourists. These communities are boat owners, food and beverage traders, and homestay owners. There are 40 boat owners who depend on Sempu Island, 13 for food and beverage traders, and 7 homestay owners. This number has decreased dramatically compared to the ones from 2012. One of the community's dependencies on Sempu Island is conveyed by Tumari [13]:

"My economic life depend on Sempu Island through its surrounding coral reef ecosystem which is still well preserved at this time. The coral reef is the home of the sea fish that I caught. Sempu Island has very positive impact for everyone around Sendangbiru Beach. I am just a small fisherman who uses Sempu Island for its rich ecosystem, and aims to protect it".

Some of these communities feel the loss if Sempu Island no longer opened its tourism activities. The people already rely on life from tourism activities on Sempu Island without developing themselves to look for another life outside of Sempu Island tourist activities. One who feels a significant impact due to the decreasing number of tourists is the decreasing number of homestay visitors, as shown in the following graph: 


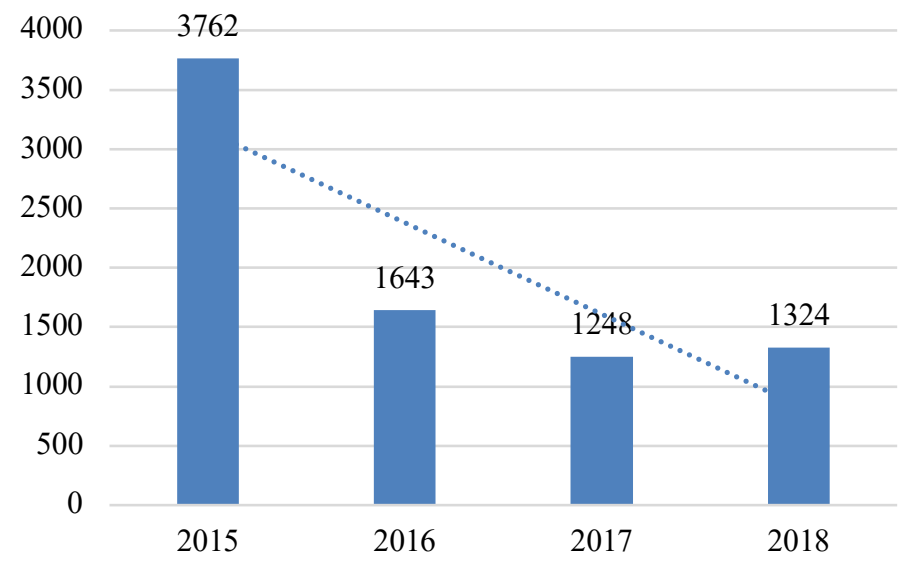

Fig. 2. Numbers of Homestay Visitors.

Based on data on the number of households in Tambakrejo Village there are 2,512 households, 332 households of them belong to the category of poor families. Most of these poor families are located on the coast of Sendang Biru Beach, where the majority of the population are small fishermen [14]. This poverty factor is the cause that makes some fishermen still depend their lives from Sempu Island.

Utilization of Sempu Island as a tourist area actually is only felt by a handful of the surrounding population. Namely some communities who work in the Sempu Island Region. For the village government itself due to the lack of transparency its benefits cannot be proved, especially related to the benefits of income that should be in accordance with the existing Perdes can provide income to the Original Village Revenue (Pendapatan Asli Desa (PADes)).

In addition to the Government of Tambakrejo Village, BBKSDA of East Java has also submitted a change to the status of Sempu Island. However, this is considered as a stage of evaluating the feasibility of regional functions. This process provides an assessment on whether this area is still suitable and relevant as a Conservation Area or not [15].

\subsection{Sempu Island Mapping Block}

BBKSDA conducted a study of Sempu Island as a conservation area by mapping blocks. This mapping aims to simplify the monitoring process carried out by officers in the island region. The mapping blocks of Sempu Island can be seen in the table below:

Table 2. Sempu Island Management Block Design

\begin{tabular}{clcc}
\hline No. & \multicolumn{1}{c}{ Block } & Areas (Ha) & Percentage \\
\hline 1 & Protection & 866,18 & 98,77 \\
2 & Rehabilitation & 7,2 & 0,82 \\
3 & Religious, Cultural/Historical & 3,62 & 0,41 \\
\hline
\end{tabular}

The protection block is the most extensive block in Sempu Island with a total area of 866 Ha. There are four lakes that are formed from topographic factors. Those lakes are Telaga Lele, Telaga Panjang, Telaga Sat and Segara Anaka. The four lakes have a hydrological function as a source of fresh water for wildlife on Sempu Island. Telaga Lele is the only source of fresh 
water that can be used as a place for animals to drink in the Conservation Area throughout the whole year. In the protection block there is also an endemic flora of Sempu Island, Myristica tesmanii, which is located along the Waru-Waru Beach to Telaga Lele and Sindur (Sindora javanica) which is endemic to East Java. The Myristica teysmannii was labelled as a critical status due to the critical existence of this plant, which is included in the Red List of Endangeres IUCN 2018. Sempu is a habitat for various types of aves, reptiles and protected mammals, among them are Javanese Hawk (Nisaetus bartelsi), White Belly Sea Hawk (Haliaetus leucogaster), Sanca Bodo (Python molurus), Javanese Lutung (Trachipithecus auratus, Deer (Muntiacus muntjak) and Panther (Panthera pardus). Activities that can be carried out in the Protection Block including [16]:

a) Protection and security;

b) Inventory and monitoring of biological natural resources and their ecosystems;

c) Scientific research and development;

d) Education and raising awareness for nature conservation;

e) Utilization of biodiversity sources to support cultivation;

f) Development of limited facilities and infrastructure.

The rehabilitation block in Sempu Island Conservation Area covers 7.2 hectares. This rehabilitation block area is located on the right and left side of the patrol line with an area of 30 meters ( 15 meters right side and 15 meters left side) along 2,400 m from Teluk Semut to Segara Anakan. Efforts to restore ecosystems are carried out through natural succession. Activities that can be carried out in the rehabilitation block including [16]:

a) Protection and security;

b) Inventory and monitoring of biological natural resources and their ecosystems;

c) Scientific research and development;

d) Education and raising awareness for nature conservation;

e) Utilization of biodiversity sources to support cultivation;

f) Restoration of ecosystems through natural mechanisms and restoration;

g) Wildlife release;

h) Development of limited management infrastructure.

The area of religious, cultural and historical block in Goa Macan reaches $2.02 \mathrm{Ha}$ consisting of a trekking path from Goa Macan Beach to Goa Macan. In addition to that, religious, cultural and historical block also located in Goa Air Tawar covering an area of 1.60 Ha. This block area consists of a trekking path from Air Tawar Beach to Air Tawar Spring and Goa Air Tawar. Activities that can be carried out in religious, cultural and historical blocks including [16]:

a) Protection and security;

b) Inventory and monitoring of biological natural resources and their ecosystems;

c) Scientific research and development;

d) Education and raising awareness for nature conservation;

e) Utilization of biodiversity sources to support cultivation;

f) Organizing cultural ceremonies and/or religious customs;

g) Maintenance of religious, cultural and/or historical sites.

This block mapping serves as a form to makes Sempu Island as a conservation area. This is based on the results of public consultations on the Long-Term Management Plan of Sempu 
Island Conservation Area of Malang Regency in 2019-2028 No. BA.135/K-2BKWIII/KSA/ 12/2018. This Public Consultation was attended by several stakeholders including:
a) KSDA of Region III Jember;
b) Technical Division of BBKSDA of East Java;
c) Representatives from UGM;
d) Malang Regency Tourism and Culture Office;
e) Bappeda of Malang Regency;
f) Malang Regency Fisheries Service;
g) UPT PHW V of Forestry Office of East Java;
h) Malang Regency Environmental Agency;
i) LIPI Botanical Garden of Purwodadi;
j) Head of SKW VI Probolinggo;
k) Head of Data Evaluation, Reporting and Public Relations Subdivision;
1) POLAIRUD Sendang Biru;
m) Sendang Biru Navy Post;
n) RKW 21 CA Sempu Island;
o) Tambakrejo Village;
p) Representative of Sendang Blue boat owners;
q) Aliansi Peduli CA Sempu Island;
r) PROFAUNA Indonesia;
s) Sahabat Alam Indonesia.

\subsection{Challenges Ahead}

Based on the results of a public consultation the decision that makes Sempu Island a conservation area presents a new challenge as in how to implement the decision. In addition to that, synergy from various actors in maintaining and protecting the status of Sempu Island is needed. This is to ensure that the status of Sempu Island is as its status suggests, namely as a conservation area.

Sempu Island as a conservation area serves more for the benefits of environmental preservation. The decision to make Sempu Island as a Conservation Area so as to maintain the Sempu Island ecosystems consisting of mangrove forests, coastal forests and lowland tropical rain forests and Segara Anakan. This shows evidence of government support for sustainable ecological development. Ecological benefits can only be felt in the long run, so it cannot be calculated in comparison with the economic value of the results of the management of Sempu Island if it is opened for tourism, under the pretext of the needs of people who depend their lives on Sempu Island.

Administrators must be firm in conducting counseling and outreach to communities around the area and to the general public regarding the status of Sempu Island as a conservation area. In addition, the importance of the firmness of BBKSD regarding the prohibition of tourism activities on Sempu Island, where every visit to the Island must bring SIMAKSI. In addition, community empowerment for the people whom previously relied their economic life from tourism activities on Sempu Island is needed. The village government in particular can provide empowerment programs so that people who depend on Sempu Island tourism activities can switch to other jobs. So that the decision to make Sempu Island as a conservation area does not cause negative impacts for some people. 


\section{Conclusion}

Sempu Island as a conservation area is under the authority of the Natural Resources Conservation Center (Balai Besar Konservasi Sumber Daya Alam (BBKSDA)) of East Java Province and is assisted by the Natural Resources Conservation Center (Balai Konservasi Sumber Daya Alam (BKSDA)) Resort as supervisor for the Sempu Island Conservation Area. As a tourist area it is regulated in Village Regulation No. 3 of 2015. However, this Perdes no longer applies due to the changes in the head of village position. However, the surrounding community is already dependent on economic activities around Sempu Island.

Based on the results of public consultations conducted by representatives of several stakeholders from the government, NGOs and community representatives decided to make Sempu Island a conservation area. Sempu Island can only be used for scientific research and development activities, education and activities that support cultivation. Therefore, every visitor who comes to the island must bring SIMAKSI. This decision is a proof of government support in terms of ecological development.

In the future, it is necessary to further promote counseling and outreach to the community related to the status of Sempu Island as a conservation area, as well as the strictness of providing sanctions for parties who violate stipulated provisions. In addition, the study of environmental politics, especially in the southern coast region of Malang Regency, in addition to a study of tourism growth in Malang Regency.

\section{References}

[1] BBKSDA Jawa Timur, "Cagar Alam Pulau Sempu," BBKSDA Jawa Timur. [Online]. Available: http://bbksdajatim.org/cagar-alam-pulau-sempu-2. [Accessed: 11-Mar-2018].

[2] Undang Undang No. 5 Tahun 1990 tentang Konservasi Sumberdaya Alam Hayati dan Ekosistemnya. 1990.

[3] C. Seftyono, "Local Community in Valuing Ecosystem Services: Warga Kampung Code's Perspective on Kali Code Existence," in Proceeding 1st Annual Indonesian Scholars Conference in Taiwan, 2010, vol., no., p. .

[4] "Peraturan Pemerintah Nomor 28 Tahun 2011 tentang Pengelolaan Kawasan Suaka Alam dan Kawasan Pelestarian Alam," 2011.

[5] A. A. Pratama and A. Maryudi, "Analisis Kebijakan Pemanfaatan Cagar Alam Pulau Sempu, Kabupaten Malang, Provinsi Jawa Timur," Ungraduated Thesi Univ. Gadjah Mada, 2014.

[6] Basyori and M. Masoed, "Konflik Pengelolaan Kawasan Cagar Alam Pulau Sempu: Antara Kebutuhan Konservasi dan Pariwisata," Ungraduated Thesi Univ. Gadjah Mada, 2015.

[7] H. Purnomo, B. Sulistyantara, and A. Gunawan, "Peluang usaha ekowisata di kawasan cagar alam Pulau Sempu, Jawa Timur,” J. Penelit. Sos. dan Ekon. Kehutan., vol. 10, no. 4, p. 29004, 2013.

[8] R. L. Bryant and S. Bailey, Third world political ecology. Psychology Press, 1997.

[9] K. Rachmat, “Teknik praktis riset komunikasi," Jakarta, PT Kencana Prenada Media Gr., 2006.

[10] A. Strauss and J. Corbin, "Dasar-dasar penelitian kualitatif," Yogyakarta: Pustaka Pelajar, 2003.

[11] BBKSDA Jawa Timur, "Tugas Pokok dan Fungsi," http://bbksdajatim.org/. [Online]. Available: http://bbksdajatim.org/tugas-pokok-dan-fungsi-1520.

[12] R. N. Sahid, "Interview with Head of PROFAUNA, 11 Februari 2019."

[13] Tumari, "Interview with Fishermen at Sendangbiru Beach, 28 Juni 2019."

[14] Desa Tambakrejo, "Data Kependudukan dan Kepala Keluarga," 2018.

[15] N. Rahman, "Interview with Head of the Planning and Preservation Section, BBKSDA Jawa Timur, 5 Maret 2019."

[16] BBKSDA Provinsi Jawa Timur, Rancangan Blok Pengelolaan Cagar Alam Pulau Sempu. 2018. 